\title{
Effect of Drechslera bicolor Infection on Physiology of Bell Pepper
}

\author{
Kuldeep Singh Jadon* and Rakesh Shah \\ Department of Plant Pathology, Rajasthan College of Agriculture, Maharana Pratap University of Agriculture and Technology, Udaipur (Rajasthan)- 313 001, India
}

\begin{abstract}
A study using susceptible cultivar (cv Bombay red) to D. bicolor grown under inoculated (infected) and noninoculated (healthy) conditions in the field at Department of Plant Pathology (R. C. A.), Udaipur. Data were recorded on different physiological parameters i.e. chlorophyll 'a', total chlorophyll, carotenoids content, chlorophyll stability index, photoactive radiation, leaf temperature, leaf area index and photosynthesis decreased in the infected plant compare to healthy plant while chlorophyll ' $b$ ', membrane permeability, transpiration rate, cuvette temperature, stomatal conductance, internal $\mathrm{CO}_{2}$ concentration, relative humidity and vapour pressure deficit increased in the infected plant compare to healthy plant. In addition, total sugar, mineral status, water status were also decreased in the infected plants compare to healthy plants. However, the superoxide dismutase enzyme activity was very high in healthy plants compared to infected plants. These results indicated that the maintenance of physiological function during leaf blight infection could result in improved bell pepper yields under diseased conditions.
\end{abstract}

Keywords: Bell pepper; Leaf blight; D. bicolor, Infected plant; Plant physiology; Nutrient status; Healthy plant; SOD

\section{Introduction}

Bell pepper or sweet pepper [Capsicum annuum var. grossum (L.) Sendt.] is regarded as one of the most popular and nutritious vegetable. Bell pepper is not only rich in nutrients but also adds a dash of colour to food. A wonderful combination of tangy taste and crunchy texture, which are the Christmas ornaments of the western world. Although, peppers are abundant and tasty during the month of August and September, however they are consumed throughout the year [1]. During cultivation, this vegetable is attacked by a large number of diseases caused by various plant pathogens, which reduce the potential yield drastically. These pathogen also attack during transit and storage. Major fungal diseases of capsicum are damping off (Phythium aphanidermatum and Phytophthora spp.), leaf spots (Cercospora capsici and Alternaria solani), anthracnose and ripe rot (Colletotrichum capsici) and fruit rot and leaf blight (Phytophthora spp.), powdery mildew (Erysiphe cichoracearum and Leveillula taurica), early blight (Alternaria solani), wilt (Fusarium oxysporum), frog eye rot (Phaeoramularia capsicicola), leaf spot (Septoria lycopersici), fruit spot (Phoma destructiva), stem rot (Macrophomina phaseoli), dry rot (Sclerotium rolfsii) and fruit rot (Phomopsis spp.), respectively. The post harvest rots are caused by Aspergillus terrues, A. candidus, A. niger, Fusarium moniliformae, F. sporotrichoides, Paecilomyces varioti and Penicillium cyolophilum [1-3]. Sharma and Sohi [4] reported a new disease of chilli caused by Drechslera sp. during kharif 1977-78 causing leaf blight and fruit rot of cv. NP-46A. They found symptoms on margins of leaf lamina, spots on stem, branches and fruits; symptoms on fruit consist of water soaked brown black areas. Seed from infected fruit show very poor germination. Deena and Basuchoudhary [5] reported D. bicolor on seeds of Capsicum annuum at Varansi (UP) and same was also compiled by Jamaluddin et al. [6] During the month of August 2006, a fungal blight caused by Drechslera bicolor was observed on the leaves of bell pepper plants (cv. Bombay red and Nun 3020 yellow) at Hi-tech Polyhouse Farm, RCA, Udaipur and later on fungal rot was also observed on fruits. The diseased plant parts were brought to the laboratory and pathogenicity was proved. Fungal culture was sent for identification at ITCC, IARI, New Delhi and identified (id. No. 279/6513-07) as D. bicolor (Mitra) [7]. The adjoining farmers' fields around Udaipur were also getting infection of this fungal pathogen. On the basis of its regular occurrence on the emerging vegetable crop in the Udaipur (Rajasthan), and very little information is available on physiology of blight infected bell pepper plant, it was decided to study this disease. Therefore, the aim of the present study was to assess the extent of deviation in physiology of blight infected bell pepper plant. The information on physiological resistance of bell pepper plant against D. bicolor can be utilized by breeders and pathologists for resistance breeding.

\section{Materials and Methods}

For the present study, part of Ph.D. thesis, an experimental trial conducted at the pathology research field of Rajasthan College of Agriculture, Udaipur, Rajasthan, India ( $73^{\circ} 42 \mathrm{E}$ longitude, $24^{\circ} 35 \mathrm{~N}$ latitude) in the year 2008 where 15 days old seedlings of susceptible cultivar (cv Bombay red) were sprayed with conidial suspension of 2 week old culture of Drechslera bicolor isolate @ $10^{4}$ conidia/ ml using hand sprayer. The observations were taken at 30 days after transplanting (DAT). For monitoring changes in chlorophyll content, leaf area index and gas exchange parameters of blight infected bell pepper leaves, the plants were randomly selected and single leaf from plant was tagged. Fully expanded leaves, well exposed to sunlight, free from any abnormalities and of similar age ( $4^{\text {th }}$ to $5^{\text {th }}$ leaf from top) were taken as healthy. Similar leaves having initiation of leaf blight infection showing mild chlorosis were selected for diseased category. For each sampling, six replicates were maintained and six leaves were selected per treatment. Same plant and leaves were taken as sample for further analysis. Chlorophyll, carotenoids contents and chlorophyll stability index (CSI) of samples were estimated quantitatively by spectrocolorimeter. Membrane permeability [electrolyte leakage] was estimated by electronic conductivity method. Carbon assimilation

*Corresponding author: Kuldeep Singh Jadon, Department of Plant Pathology, Rajasthan College of Agriculture, Maharana Pratap University of Agriculture and Technology, Directorate of Groundnut Research, Junagadh - 362 001, Gujarat, India, E-mail: kuldeep.rca@gmail.com

Received July 11, 2012; Accepted July 30, 2012; Published August 07, 2012

Citation: Jadon KS, Shah R (2012) Effect of Drechslera bicolor Infection on Physiology of Bell Pepper. J Plant Pathol Microb 3:126. doi:10.4172/21577471.1000126

Copyright: ( 2012 Jadon KS, et al. This is an open-access article distributed under the terms of the Creative Commons Attribution License, which permits unrestricted use, distribution, and reproduction in any medium, provided the original author and source are credited. 
Citation: Jadon KS, Shah R (2012) Effect of Drechslera bicolor Infection on Physiology of Bell Pepper. J Plant Pathol Microb 3:126. doi:10.4172/2157-

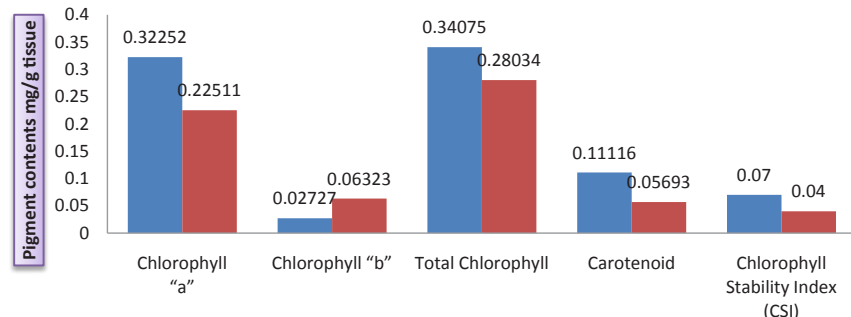

Healthy Diseased

Figure 1: Chlorophyll, carotenoid and chlorophyll stability index (CSI) in healthy and blight infected leaves of bell pepper.

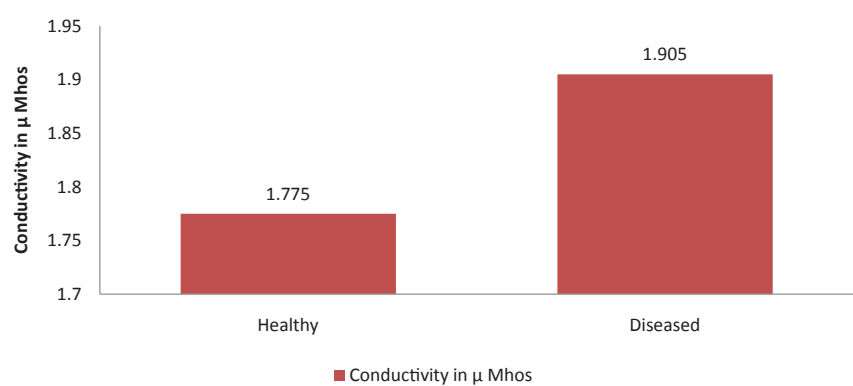

Figure 2: Membrane permeability [electrolyte leakage] of healthy and blight infected leaves of bell pepper.

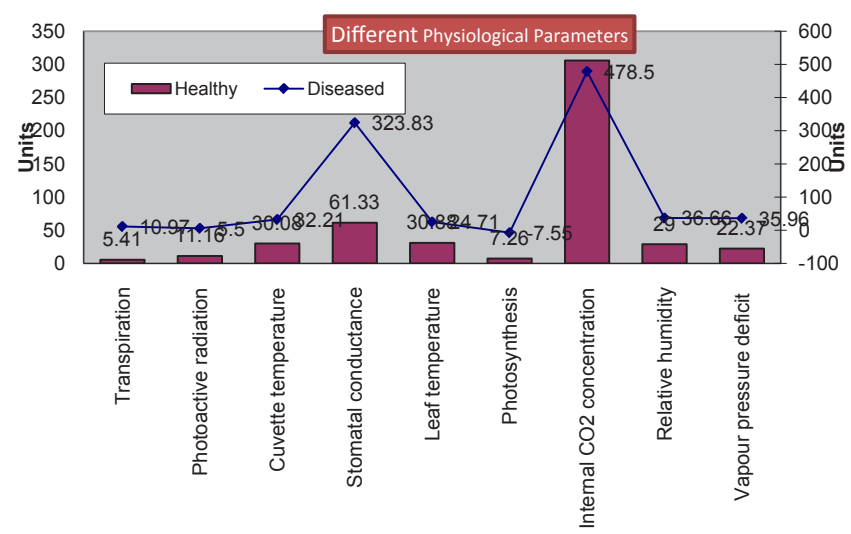

Figure 3: Transpiration, photoactive radiation, cuvette temperature, stomatal conductance, leaf temperature, photosynthesis, internal carbon dioxide concentration, relative humidity and vapour pressure deficit, in healthy and blight infected leaves of bell pepper.

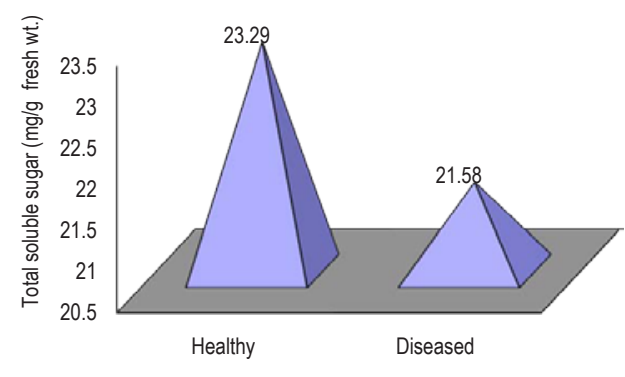

口Total soluble sugar ( $\mathrm{mg} / \mathrm{g}$ fresh $\mathrm{wt}$.)

Figure 4: Total soluble sugar in healthy and blight infected leaves of bell pepper.

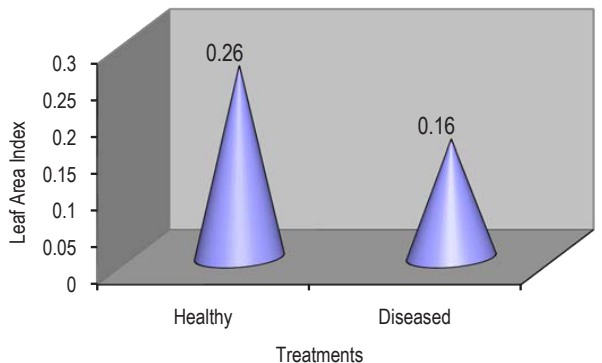

QLeaf area index

Figure 5: Leaf area index (LAI) of healthy and blight infected leaves of bell pepper.

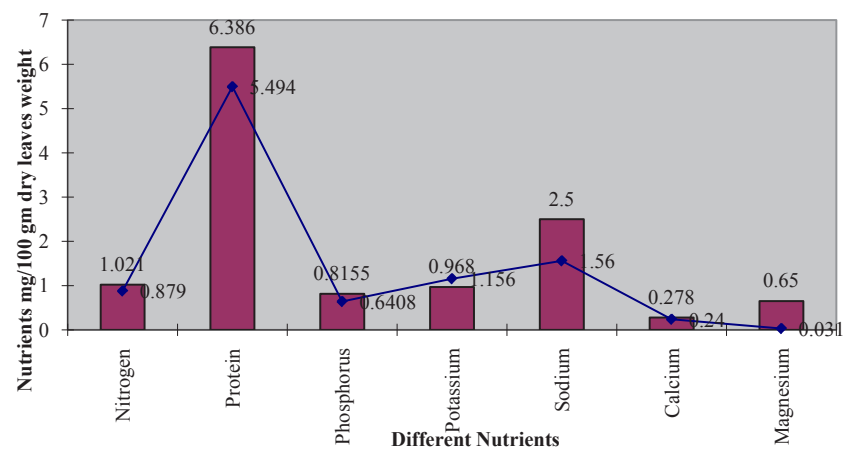

Figure 6: Nutrient status of healthy and blight infected leaves of bell pepper.

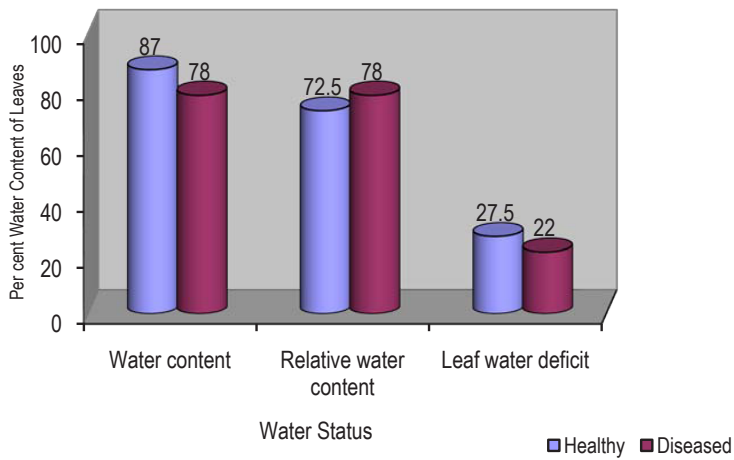

Figure 7: Water status of healthy and blight infected leaves of bell pepper.

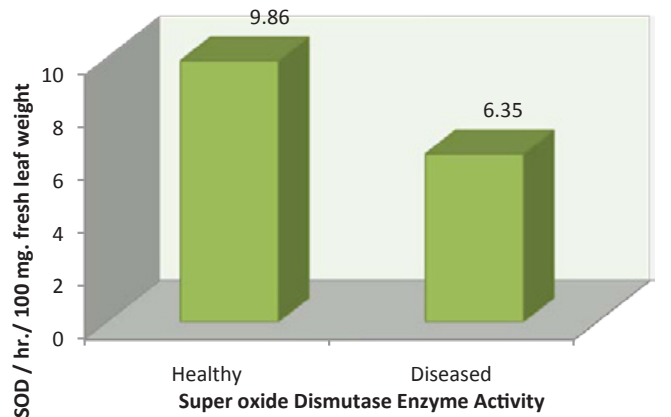

SOD / hr./ 100 mg. fresh leaf..

Figure 8: Super oxide dismutase enzyme activity in healthy and blight infected leaves of bell pepper. 


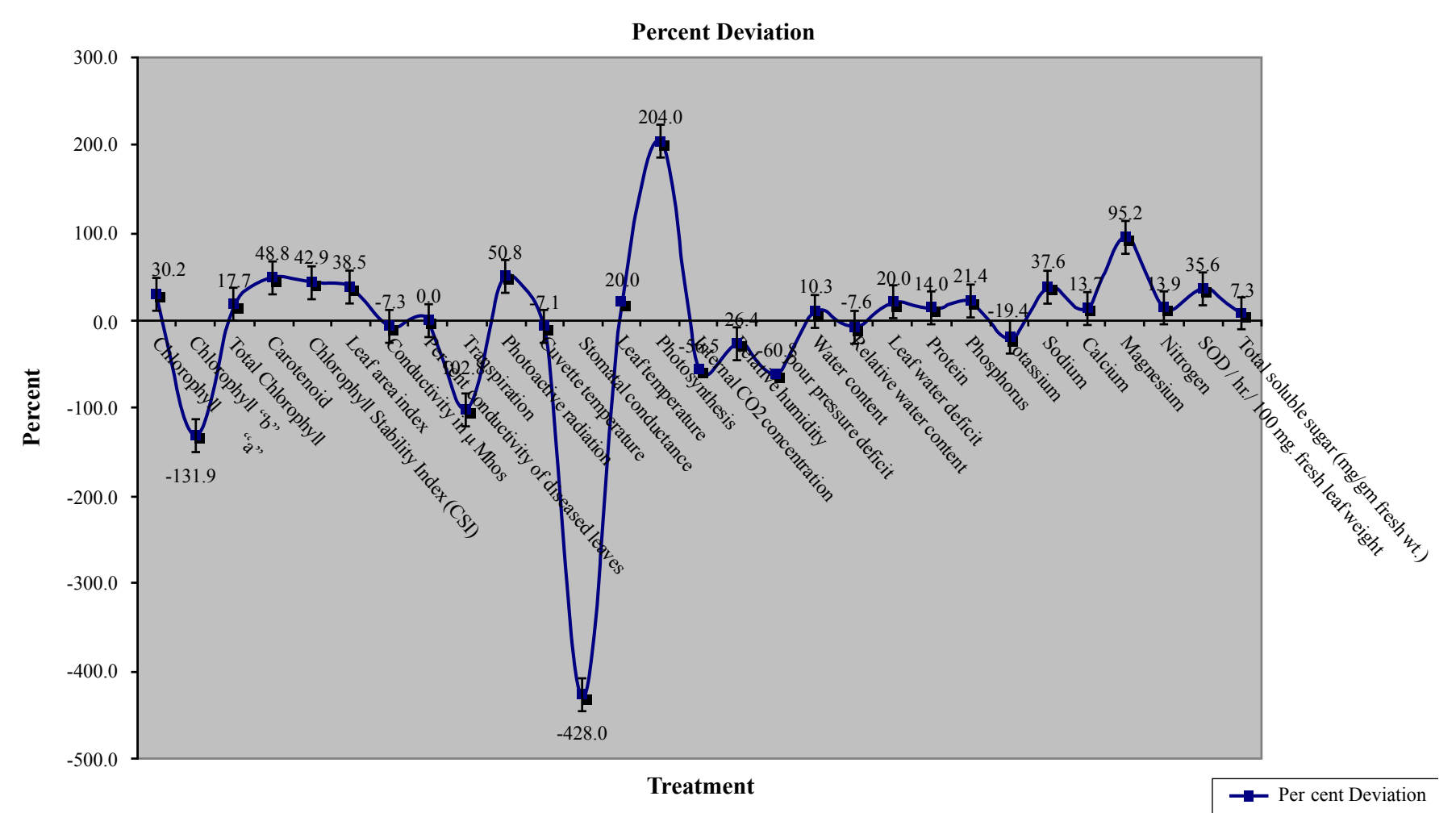

Figure 9: Per cent deviation in infected plant compare to healthy plant

rate were measured between 10-12 h AM by CIRAS-2 Portable Photosynthesis System under natural radiation. Total sugar was estimated by anthrone method, Hedge and Hofreiter [8]. Leaf area index (LAI) was measured between 10-12 AM by Canopy Analyser (LP80) under natural radiation and was expressed in lux. The concentrations of phosphorus were estimated using Kjeldahl flask, and sodium, calcium, potassium and magnesium were estimated using flame photometer method. The total nitrogen and protein contents were estimated by micro-kjeldahl method. The water status was estimated by oven dry method. The relative water content and leaf water deficit in leaves were estimated by micro- oven dry method. Superoxide dismutase (SOD) enzyme activity by scavenging $\mathrm{O}_{2}^{-}$, is a key component in the free radical detoxification process. $\mathrm{SOD}$ enzyme activity measuring the ability to inhibit the photochemical reduction of NBT in presence of riboflavin in the light at $560 \mathrm{~nm}$. One unit of SOD activity was defined as the amount of enzyme which caused $50 \%$ inhibition of the initial rate of reaction in the absorbance of enzyme. The superoxidase dismutase (SOD) enzyme activity of the plant material was measured as described by Beauchamp and Fridovich [9]. Data on healthy and infected leaves were subjected to paired $t$ test at $\mathrm{p}=0.05$.

\section{Results}

In infected leaves, chlorophyll 'a' was decreased to 30.20 per cent (Figure 1) while an increase in chlorophyll 'b' was recorded as 131.87 per cent, and per cent decrease in total chlorophyll was 17.73 per cent. The carotenoid content in healthy leaves was $0.11 \mathrm{mg} / \mathrm{g}$ fresh weight (f.w.), whereas it was $0.05 \mathrm{mg} / \mathrm{g}$ (f.w.), in infected leaves giving a reduction of 48.79 per cent. In infected leaves the CSI was $0.04 \mathrm{mg} / \mathrm{g}$ (f.w.), whereas it was $0.07 \mathrm{mg} / \mathrm{g}$ (f.w.) in healthy leaves and shows reduction of CSI as 42.86 per cent in infected leaves.
The Figure 2 clearly indicates that membrane permeability in infected leaves increased appreciably (7.32 per cent) as compared to healthy leaves. The healthy leaves had $1.78 \mu$ mhos membrane permeability against $1.91 \mu$ mhos in infected leaves. The per cent conductivity in infected leaves was 93.17.

It is evident from Figure 3 that transpiration, photoactive radiation, cuvette temperature, stomatal conductance, leaf temperature, photosynthesis, internal carbon dioxide concentration, relative humidity and vapour pressure deficit, were deviated in the infected leaves of bell pepper. It was observed that in infected leaves, the transpiration rate was higher 102.77 per cent as compared to healthy leaves. In other physiological factors the per cent deviations were 50.77 in photoactive radiation; 7.08 per cent in cuvette temperature; 428.01 per cent in stomatal conductance; 19.98 per cent in leaf temperature; 203.99 per cent in photosynthesis; 56.45 per cent in internal $\mathrm{CO}_{2}$ concentration; 26.41 per cent in relative humidity and 60.75 per cent in vapour pressure deficit, respectively. The total sugar content was 23.29 $\mathrm{mg} / \mathrm{gm}$ (f.w.) in healthy leaves against $21.58 \mathrm{mg} / \mathrm{gm}$ (f.w.) in infected leaves. The amount of total sugar was decreased to 7.34 per cent in infected leaves (Figure 4).

Figure 5 revealed that LAI in infected leaves was decreased appreciably (38.46 per cent) compared to healthy leaves. The healthy leaves had 0.26 lux against 0.16 lux in infected leaves. The amount of five elements varied in infected leaves (Figure 6). Figure 6 indicated that the total nitrogen and protein contents in infected leaves decreased appreciably (13.91 and 13.97 per cent, respectively), phosphorus, sodium, calcium and magnesium contents decreased up to 21.42 , $37.60,13.67$ and 95.23 per cent, respectively, while potassium content increased up to 19.42 per cent, compared to healthy leaves. The Figure 7 indicated that the water status in infected leaves decreased appreciably 
(10.34 per cent) as compared to healthy leaves. Figure 7 indicated that the RWC in diseased leaves decreased appreciably (7.59 \%) compared to healthy leaves. The LWD in diseased leaves decreased appreciably (20.00 \%) compared to healthy leaves. The healthy leaves had 27.5 per cent of LWD as against 22.0 per cent in diseased leaves. The results in Figure 8 indicated that the difference in SOD activities between healthy and infected leaf tissues were significant; the decrease over healthy was 35.60 per cent. The results in Figure 9 show the Percent deviation in infected plant compare to healthy plant.

\section{Discussion}

Drechslera bicolor (Mitra.) Subram and Jain causes leaf blight in bell pepper [Capsicum annuum var. grossum (L.) Sendt.] which leads to necrotic lesions, early leaf senescence and yield losses. Detailed physiological analysis can contribute to an improved understanding of bell pepper-disease interaction and cultivar improvement. The photosynthetic activity decreased in the bell pepper blighted leaves and similarly John [10] and Aguirreolea et al. [11] detected reduced levels of photosynthetic activities in rice cv. IR-2 (H. oryzae) and bell pepper cv. Morron (Phytophthora capsici). The reduction in chlorophyll was correlated with symptom development and disease severity while in the present case chlorophyll 'a' was decreased in diseased leaves and chlorophyll 'b' was increased. Singh and Singh [12] studied infection by cucumber mosaic in capsicum and found reduced total chlorophyll, chlorophyll 'a' and chlorophyll 'b' but to a greater extent in susceptible cultivars than resistant ones. Verma et al. [13], Kumar and Singh [14], Singh et al. [15] and Hossain et al. [16] also reported reduction in chlorophyll contents in cases of Colletotrichum falcatum (sugarcane), Alternaria alternata (sunflower), Puccinia calcitrape var. centaureae (safflower) and Colletotrichum gloeosporioides (mango) leaves. In the present studies, protein contents were appreciably decreased in diseased bell pepper leaves. Sharma and Sharma [17] concluded that increased concentration of proteins and other biochemicals in resistant variety may play a role in the inhibition of infection. Singh and Waraitch [18] also reported reduction in protein content in diseased leaves of sugarcane by Colletotrichum falcatum. The total nitrogen and protein were decreased in bell pepper diseased leaves but Jeyarajan and Ramakrishnan [19] studied potato virus Y infected chilli leaves and found total nitrogen, protein $\mathrm{N}$ and amide $\mathrm{N}$ contents increased and the nitrate $\mathrm{N}$ decreased compared to healthy leaves, but ammonium $\mathrm{N}$ and non protein $\mathrm{N}$ levels were not affected. The superoxide dismutase enzyme activity (SOD) was very high in healthy leaves compared to diseased leaves during present investigations whereas on contrary Scandalios [20] observed an increased SOD activity in tissues of oat at $40 \mathrm{~h}$ with Drechslera arenae but no such increase was observed in oat leaves inoculated with $D$. nobleae by Gonner and Schlosser [21]. The results on the decrease in SOD activity during present studies by D. bicolor was strongly supported by the work of Rawal et al. [22] and Jingao et al. [23] where this activity decreased significantly in plants inoculated with Fusarium solani (Sponge gourd) and Alternaria brassica (Chinese cabbage), respectively.

\section{References}

1. Chadda KL (2003) Capsicum. Hand Book of Horticulture. Indian Council of Agriculture Research, New Delhi 3: 368-371.
2. Gupta VK, Paul YS (2002) Disease of Vegetable Crops. Scientific Publishers (India) Jodhpur 96-102.

3. Gupta SK, Thind TS (2012) Disease problems in vegetable production Jodhpur, India: Scientific Publishers.

4. Sharma SR, Sohi HS (1980) New disease of chillies caused by Drechslera Current Science 49: 747-748.

5. Deena E, Basuchaudhry (1984) Studies on seed borne mycoflora of chilli. Indian Phytopathology 37: 151-153.

6. Jamaluddin, Goswami MG, Ojha BM (2004) Fungi of India 1989-2001. Jodhpur, India: Scientific Publishers 51.

7. Sapnesh Didvaniya (2007) Physiological and pathological studies of Drechslera bicolor causing blight of bell pepper Capsicum annuum var. grossum. M.Sc thesis submitted to MPUA\&T, Udaipur, Rajasthan.

8. Hedge JE, Hofreiter BT (1962) In: Carbohydrates Chemistry, 17 vol (Eds) Academic Press, New York 91.

9. Beauchamp C, Fridovich J (1971) Superoxide dismutase: improved assay and an assay applicable to acrylamide gels. Anal Biochem 44: 276-287.

10. John SA (1996) Physiology of rice as influenced by senescence and pathogenesis. Madras Agricultural Journal 83: 365-367.

11. Aguirreolea J, Irigoyen J, Sanchez-Diaz M, Salaverri J (1995) Physiological alterations in pepper during wilt induced by Phytophthora capsici and soil water deficit. Plant Pathol J 44: 587-596.

12. Singh MJ, Singh J (1991) Effect of Cucumber Mosaic Virus on chlorophyll pigments in chillies (Capsicum annuum L.) Vegetable Science 18:200-208

13. Verma RK, Rao GP, Verma KP, Singh HN (1991) Some biochemical changes in red rot infected sugarcane leaves. Indian Sugar 40: 817-820.

14. Kumar R, Singh SB (1996) Change in biochemical constituents if sunflowe leaves in relation to Alternaria blight development. Journal of Mycology and Plant Pathology 26: 234-236.

15. Singh, Reeti, Pandya RK, Khare MN (1998) Biochemical changes in sufflowe leaves infected by rust (Puccinia calcitrape var. centaureae). Journal of Mycology and Plant Pathology 28: 164-167.

16. Hossain MT, Alam MZ, Absar N (1999) Changes in different nutrients and enzyme contents in mango leaves infected with Colletotrichum gloeosporioides. Indian Phytopathology 52.

17. Sharma AR, Sharma DK (1994) Biochemical and histological studies on susceptible and resistant maize leaves infected by Helminthosporium maydis. Plant Pathol J 43: 972-978.

18. Singh O, Waraitch KS (1981) Effect of wilt and red rot induced disease stress on quality deterioration of sugarcane. Sugarcane Pathologists' Newsletter 27

19. Jeyarajan R, Ramakrishnan K (1972) Studies on the physiology of chill (Capsicum annuum L.) plant affected by Potato Virus Y. III. Effect on nitrogen metabolism. Madras Agricultural Journal 59: 23-27.

20. Scandalios JG (1990) Response of plant antioxidant defence genes to environmental stress. Adv Genet 28: 1-41.

21. Gonner MV, Schlosser E (1993) Oxidative stress in interactions between Avena sativus L. and Drechslera spp. Physiological and Molecular Physiol Mol Plant Pathol 42: 221-234.

22. Rawal P, Thakore BBL, Mathur, Sudha R, Ganesh R, et al. (1999) Pathogen induced changes in lipid peroxidation and some enzymes of activated oxygen metabolism in fruit rot of sponge-gourd, Luffa cylindrical L. (Abst.) National seminar on plant physiology at interface of Agri-Horticulture and Industry Raj Coll of Agric Udaipur 76.

23. Jingao $D$, Muzhen $F$, Jianming $H$ (1999) The effect of AB-toxin from Alternaria brassicae on membrane permeability and the activities of sod and pod in chinese cabbage leaves. Acta Phytopathologica Sinica 29: 138-141. 